\title{
LOS DESAFÍOS DE LA REPÚBLICA. NOTAS SOBRE LA POLÍTICA EN LA ARGENTINA POS CASEROS HILDA SABATO
}

Hilda Sabato es Investigadora del CONICET con sede en el Programa de Estudios de Historia Económica y Social Latinoamericana (PEHESA) del Instituto de Historia Argentina y Americana «Dr. Emilio Ravignani», de la Universidad de Buenos Aires.

Este trabajo fue escrito en el marco de un proyecto sobre la política en la Argentina de la segunda mitad del siglo XIX que cuenta con apoyo del programa UBACyT de la Universidad de Buenos Aires y que

\section{Resumen}

El artículo se propone reflexionar sobre la vida política argentina en la segunda mitad del siglo XIX en el marco de la experiencia republicana inaugurada después de la independencia. Toma como punto de partida la extensa bibliografía producida en las últimas décadas, que ha resultado en un conjunto de interpretaciones novedosas sobre dicho período. Este texto presenta y discute algunas propuestas actuales a la vez que abre nuevos interrogantes. Pone el foco inicial en las instituciones y prácticas vinculadas con «la invención del pueblo» en la república, con particular referencia a tres instancias clave: elecciones, milicias y opinión pública. Interroga, a continuación, la forma que fue tomando el pueblo concreto, para referirse luego a las dirigencias. Un tercer punto está dedicado a las organizaciones partidarias, actores centrales en las disputas por el poder. La pregunta acerca de esas disputas es materia del cuarto punto, que concluye con consideraciones acerca de la inestabilidad y el orden políticos. integra también un PICT de la ANPCyT. Las ideas que aquí se presentan son, en buena medida, el resultado de la labor colectiva realizada en el marco de dicho proyecto. La autora agradece en particular a Laura Cucchi, que leyó versiones preliminares de este texto y aportó valiosas sugerencias; y a César Tcach y a Estudios Sociales la invitación a sumarse al homenaje a Darío Macor, amigo querido con quien tuvo el privilegio de compartir muchos de los interrogantes sobre la política argentina que abonan estas páginas.

\section{Summary}

The purpose of this article is to reflect upon argentine politics during the second half of the nineteenth century, in the context of the republican experience inaugurated after independence. Its point of departure is the extensive bibliography produced in the last three decades, which has introduced decisive changes in the canonical narratives of the period. This article presents and discusses some of the current interpretations, and seeks to formulate new questions. It focuses, firstly, on the institutions and practices related to the «invention of the people» in a republic, with particular reference to three dimensions thereof: elections, militia, and public opinion. Secondly, it addresses the question of who made the concrete people, to analyze then the leaders and leaderships. A third section examines a key figure in the political disputes of the period: the "party". Finally, those disputes are the main topic of the last section, which reflects upon political order and instability. 